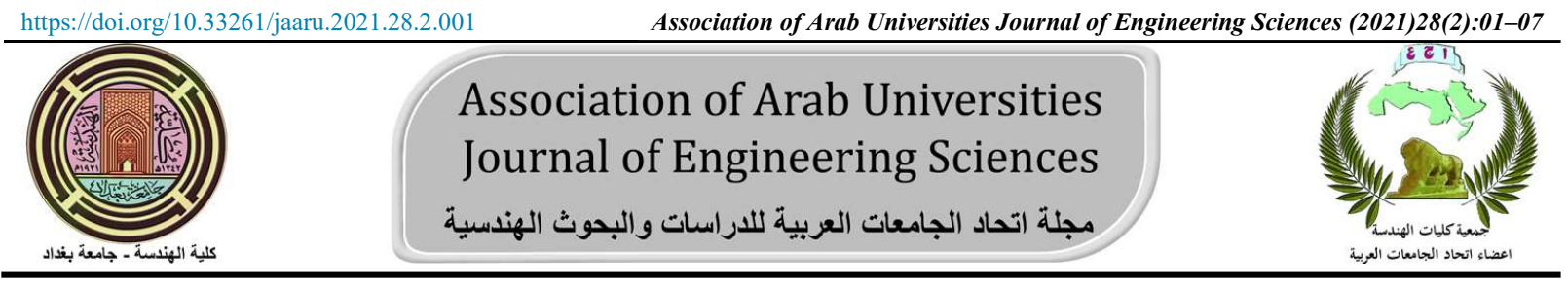

\title{
Removal of Congo Red from Aqueous Solution by Circulating Fluidized Bed(CFB)
}

\author{
Hamza Q. Ali ${ }^{1}$, Ahmed A. Mohammed ${ }^{2 *}$ \\ ${ }^{1}$ College of Engineering, University of Baghdad, Baghdad, Iraq, hamzaashter@gmail.com. \\ ${ }^{2}$ College of Engineering, University of Baghdad, Baghdad, Iraq, Country, ahmed.abedm@yahoo.com. \\ *Corresponding author : Hamza Q. Ali and email: hamzaashter@gmail.com. \\ Published online: 30 June 2021.
}

Abstract - In this study circulating fluidized bed was adopted to remove of Congo Red from wastewater using Eichhornia crassipes as a adsorbent. Solution flow rate $(6,12$ and 18)1/hr, bed height $(2,4$ and 6$) \mathrm{cm}$ and Congo Red initaial concentration (10,25 and 50)mg/l were examined in experiments to show their effects on breakthrough curves and time required to reach the adsorbent to fully saturated curve. The mass transfer coefficient $" \mathrm{~K}_{\mathrm{L}}$ "decreased with decreasing the liquid flow rate. The minimum fluidization velocities of bed found equal to $1.6,2,2.5 \mathrm{~mm} / \mathrm{s}$ for heights of $2,4,6 \mathrm{~cm}$ respectively. The increasing of the bed height will increase the contact time of the solute in the bed, and these improve the solute removal efficiency. the increasing in flow rate and initial concentration will increase the mass transfer rate.

Keywords - Congo Red dye, Eichhornia crassipes. Circulating Fluidized Bed, Minimum fluidization velocity, Mass transfer

\section{Introduction}

Fresh water is vital to human life and economic wellbeing, and societies extract vast quantities of water from rivers, lakes, wetlands, and underground aquifers but most of these freshwater sources are polluted by different chemicals discharged from industries. need for fresh water has long caused to overlook equally vital benefits of water that remains in streams to sustain healthy freshwater habitats [1][33]. Water is being polluted largely due to increased industrialization. Dyestuff manufacturing industries and many other dye and pigment-using industries such as rubber, paper, textile, plastics, and cosmetics generate highly colored and toxic effluent. During dyeing processes $50 \%$ of dye is lost. The release of these dyes containing waste water into rivers, seas has adverse effects on the people who use such contaminated water for living purposes like washing, bathing and drinking. Even a small quantity of dye (1.0 $\mathrm{mg} / \mathrm{L}$ ) in water is detectable and objectionable. Besides this dyes can influence aquatic plants by reducing transmission of sunlight into water.

Dyes are mutagenic, dangerous and cause harmful effects to humans[21], [22], [31]. In up-to-date data, more than 100,000 commercially available dyes with the rate of $7 \times$ $10^{5}$ tons per year are produced and usually two percent of the products are discharged into water systems as waste [6]. Most of the dyes are harmful when brought in contact with living tissues for a long time. The discharge of these dyes to the river stream without proper treatment causes irremediable damage to the crops and living beings, both aquatic and terrestrial [30][7]. Consequently, removal of dyes from such wastewaters is an important environmental problem and complete dye removal is needed because dyes are visible even at low concentration [26]. Anthraquinone-based dyes are the most resistant to degradation due to their fused aromatic structures, which remain coloured for a longer period of time [10].

Different procedures were developed for removal of organic dyes from wastewater. These procedures include electrocoagulation[18], flotation[3], chemical oxidation[10], filtration[12], ion exchange[16], ozonation[16], membrane separation and microbial degradation[16]. Adsorption is found a good way to treat industrial waste effluents, it has significant advantages in comparison with conventional methods, especially from economical and environmental viewpoints [13][1][8]. Natural materials or the wastes, by-products of industries or synthetically prepared materials[5], which are cheap and can be used as such or after some minor treatment as adsorbents, are generally called low-cost adsorbents [19][35][2].So many researchers search for cost effective

and efficient alternative materials such as tree fern[38], teak tree bark powder[26], orange peel[10], banana 
pith[36], date pits[20] and tea waste [29][30]. The most effective and optimized utilization of a biomass demands a detailed understanding of the binding mechanism [37]. Eichhornia crassipes is water hyacinth, found in large amounts around the fields of irrigations and in the fresh water bodies through the year in tropical and subtropical countries including Iraq [39]. The potential of using E. crassipes as alive or a dead biomass to remove dyes from solutions was recently investigated. The results showed that it is a promising cheap biosorbent source for dyes [40][34][16]. In recent years the circulated fluidized bed reactor has received extensive consideration and varied usage in the treatment of wastewater owning to its many benefits such as high contact between gas, liquid, and solid phase producing high mass transfer and high reaction rate, it could reduce the operational problems occur in packed-bed like bed clogging and high pressure drop, it is simple, highly efficient, economical operation compared to other reactor configurations and stable [6][15].This paper aims to study the process of separation and purification wastewater through the removal of Congo red using Water hyacinth (Eichhornia Crassipes)by circulated fluidized bed.

\section{Materials preparation}

\subsection{Adsorbate}

A Congo Red dye obtained from Sigma Aldrich with $99.99 \%$ purity was dissolved in distilled water to prepare $(10,25$ and 50$) \mathrm{mg} / \mathrm{L}$ concentration of CR used in the experiment work. $0.1 \mathrm{M}$ of hydrochloric acid or sodium hydroxide base was added to regulate the solution $\mathrm{pH}$ to the desired value. Congo red dye is the sodium salt of $3,3^{\prime}\left\{\left[1,1^{\prime}\right.\right.$ '-Biphenyl]-4,4'-diylbis(azo) $\}$ bis(4-amino-1naphthalene sulfonic acid disodium salt) has a molecular weight of $696.66 \mathrm{~g} / \mathrm{mol}$ with a formula $\left(\mathrm{C}_{32} \mathrm{H}_{22} \mathrm{~N}_{6} \mathrm{Na}_{2} \mathrm{O}_{6} \mathrm{~S}_{2}\right)$, and their chemical composition structure was shown in Figure 1.



Figure 1: Chemical formula of Congo Red

\subsection{Biomass preparation}

Water hyacinth (Eichhornia crassipes) was prepared as follow:

1. Collected from Tiger River in Aldora district of Baghdad.

2. Washed several times with distilled water in order to make it clean and the washed water hyacinth were left under the sunlight for five days to dry, then oven dried at $105^{\circ} \mathrm{C}$ for 2 hours to ensure that the sample dried completely.

3. Water hyacinth were separated into stems, leaves and roots.
4. The samples grinded by electric grinder and seived to different particle size as show in Figure 2.

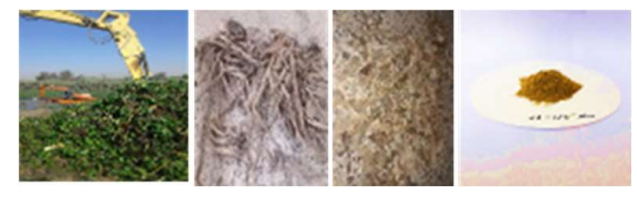

Figure 2: Water hyacinth (Eichhornia crassipes)

\subsection{Circulating fluidized bed (CFB)}

G-L-S fluidization is an operation involving a bed of suspended particles in gas and liquid media. This occurs due to a net drag force of gas and liquid in the flow direction on the particles. The solid particles are circulated between the riser and the downer. Figure 3 show the schematic diagram for CFB column used in removal of CR from wastewater and Table 1 represents the major parameters examined.

Table 1: Parameters range tested in CFB

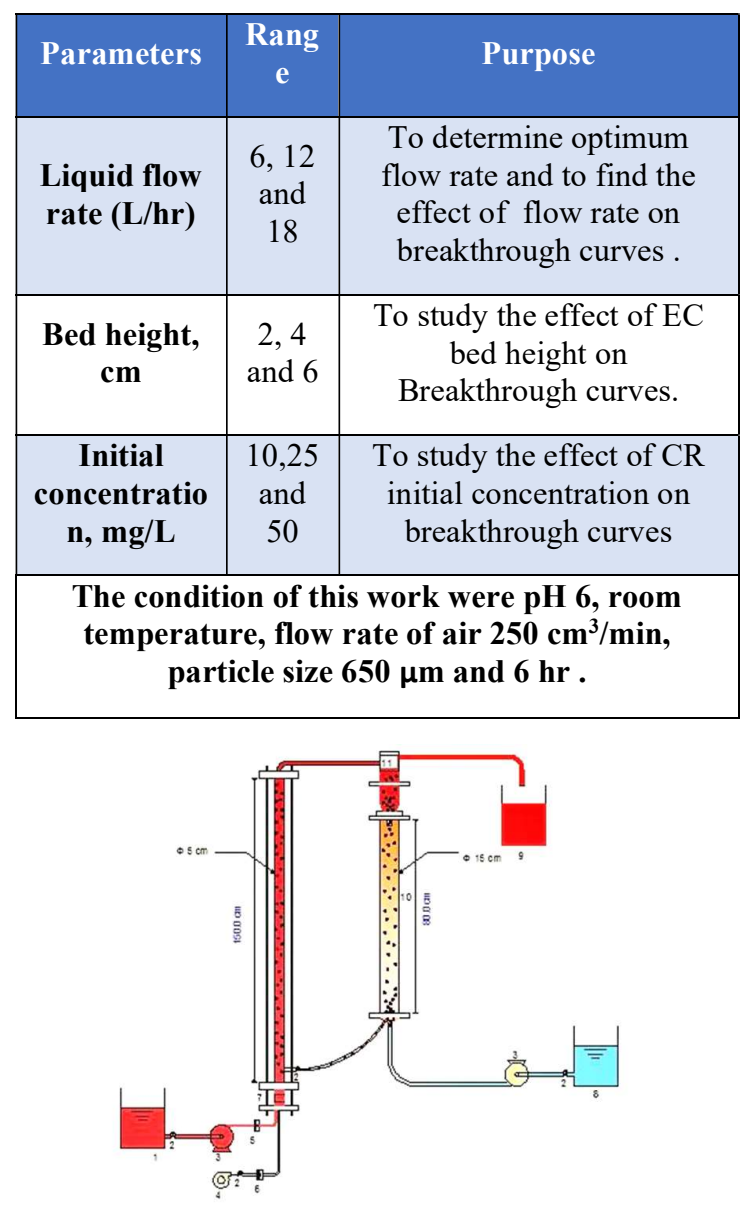

Figure 3: GLSCFB schematic diagram (1: Feeding tank, 2: Valve, 3: Pump, 4: Air compressor, 5: Flow meter of liquid, 6: Gas flow meter, 7: Distributer, 8: Distilled water for the downer 9: Treated wastewater, 10: Downer column, 11: Solid-liquid separator, 12: Riser column.) 


\section{Results and Discussion}

\subsection{Minimum fluidization velocity (Ulmf)}

The minimum fluidization velocity (Ulmf) was determined experimentally by measuring the pressure drop through the bed of adsorbent particles. The values of minimum fluidized velocity are $0.0016,0.002$ and 0.0025 $\mathrm{m} / \mathrm{s}$ for the different bed height 2,4 and $6 \mathrm{~cm}$ respectively. Ulmf in this study has been obtained as displayed in Figure 4, it is noticed that initial static bed height Hs affect Umf, when Hs increase, pressure drop increase then Umf increase. This owing to the fact that bed fluidization achieved when equaling the upward drag and inertial forces applied by the fluids on the particles with the bed buoyant weight, the initial static bed height (Hs) only effect on the Umf as expected[6].

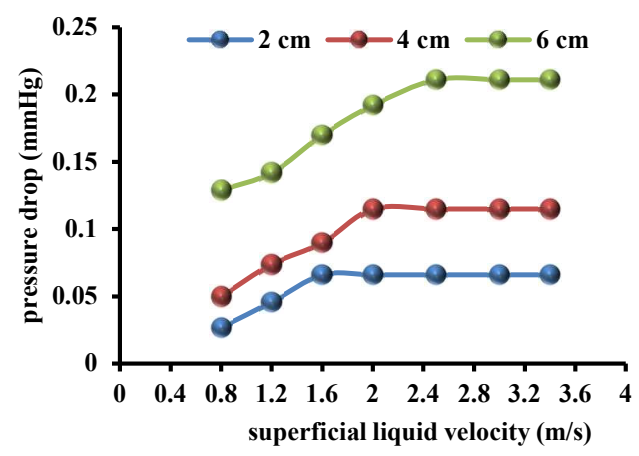

Figure 4: Pressure drop Variant with $\mathrm{U}_{\mathrm{L}}$ for different $\mathrm{H}_{\mathrm{S}}$ values

\subsection{Bed expansion}

It is important to be able to establish the relationship between the superficial liquid velocity (U) and the bed voidage $(\varepsilon)[15]$. The bed voidage of fluidized EC biomass was found experimentally using Equation (1) and compared with the theoretical value that calculated using Equation (2). Experimental and theoretical voidage ( $\varepsilon$ ) values are shown in Table 2

$\varepsilon=\frac{V_{\varepsilon}}{V_{b}} \quad=\frac{V_{b}-V_{p}}{V_{b}}=1-\frac{V_{p}}{V_{b}}=1-\frac{m_{p}}{\rho_{p} \cdot V_{b}}=1-\frac{m_{p}}{\rho_{p} \cdot A \cdot H}$ (1)

$\frac{\mathrm{U}}{\mathrm{Ui}}=\varepsilon^{n}$

Table 2: Values of $\mathrm{n}$, theoretical and experimental voidage for particle size ranges.

\begin{tabular}{|c|c|c|c|c|}
\hline $\begin{array}{c}\text { Particle } \\
\text { size } \\
(\mathrm{mm})\end{array}$ & $\begin{array}{c}\text { Uri R } \\
(\mathrm{m} / \mathrm{s})\end{array}$ & $\begin{array}{c}\text { index } \\
(\mathrm{n})\end{array}$ & $\begin{array}{c}\varepsilon \\
\text { Eq.(2) }\end{array}$ & $\begin{array}{c}\varepsilon \\
\text { Eq.(1) }\end{array}$ \\
\hline 0.7 & 0.022 & 3.87 & 0.71 & 0.93 \\
\hline
\end{tabular}

\subsection{Breakthrough Curves}

By plotting $\mathrm{Ce} / \mathrm{Ci}$ versus time for $\mathrm{CR}$, the breakthrough curves for contaminant was obtained.

\subsubsection{Effect of liquid flow rate:}

The fluid flow rate is a major parameter in the design of biosorption column especially fluidized bed reactor due to its effect on the contact time between the particles and dye solution[15]. When the flow rate increases the breakthrough curves become steeper. At a high flow rate, the adsorbate solution leaves the column before the complete equilibrium occurs due to the reduction in the contact time as shown clearly in figure below Figure5. The increasing of flow rate will cause a reduction in the thickness of the surface film which considered the resistance for the mass transfer. As a result of that increasing in flow rate will increases the mass transfer rate[12]. These results agree with that obtained by [15], [34].

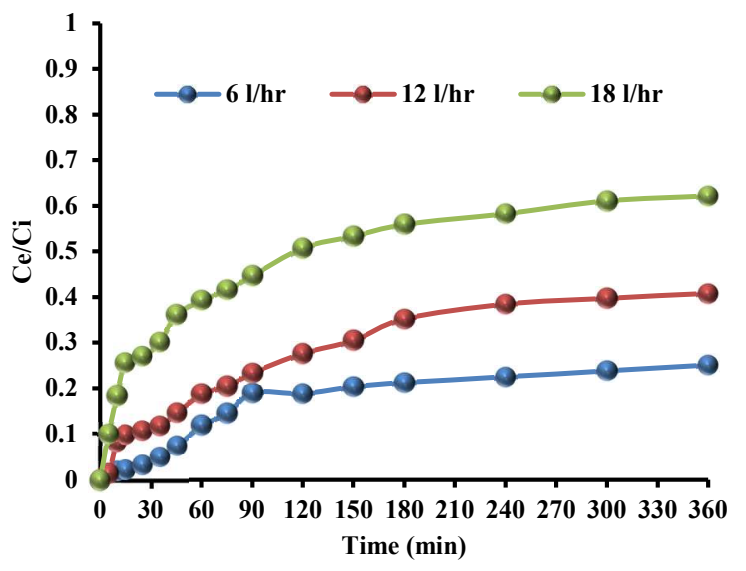

Figure 5: Effect of flow rate on removal of $\mathrm{CR}$ at initial conditions $(8 \mathrm{~cm}), \mathrm{pH} 6,10 \mathrm{mg} / \mathrm{L}$, and air flow rate 250 $\mathrm{cc} / \mathrm{min}$.

\subsubsection{Effect of bed height:}

It is obvious that when the bed height increases, the time to reach breakpoint increase. The increasing of bed height will provide an extra surface area for the adsorption process. This shows that at low bed height the effluent adsorbate concentration ratio increases more rapidly thanfor a higher bed height. Furthermore, in a low bed height, the bed is saturated in less time. A lower bed height corresponds to lesser amount of adsorbent and weak capacity for the bed to adsorb dye from solution. At constant flowrate, the increasing of the bed height will increase the contact time of the solute in the bed, and 
these improve the solute removal efficiency[17]. These results agree with that obtained by [16], [27].

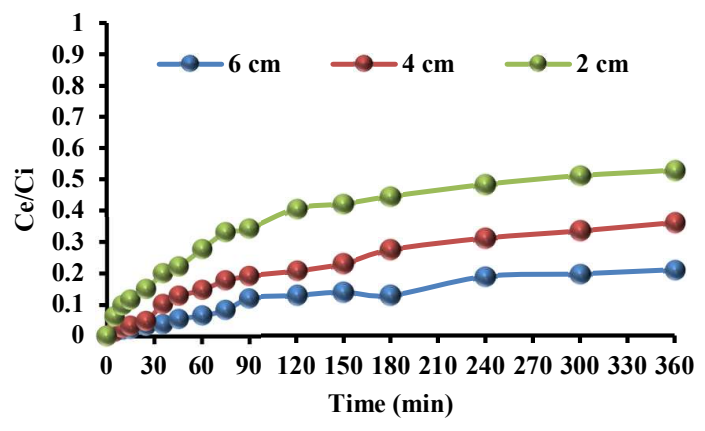

Figure 6: Effect of bed height at initial conditions $\mathrm{pH} 6$, $10 \mathrm{mg} / 1,6 \mathrm{~L} / \mathrm{hr}$, and air flow rate $250 \mathrm{cc} / \mathrm{min}$ on removal of CR.

\subsubsection{Effect of initial concentration:}

The effect of different initial CR dye concentrations (10, 25 and $50 \mathrm{ppm}$ ) on the removal efficiency were examined at constant water, air flow rate, bed height and the results were plotted in Figure7 in terms of $\mathrm{C} / \mathrm{Co}$ versus time. From this figure, it is obvious that saturation time decreases with increasing the initial concentration and there is inverse relation between the breakpoint and initial concentration. Low initial solute concentration make the saturation time of diffusion rate longer. As the CR influent concentration increases, the adsorption capacity also increase. This was attributed to a high concentration difference (driving force for adsorption) between liquid and solid phase also, this will increase solute mass transfer rate to attach adsorbent active free sites. If the initial CR concentration is high, faster bed saturation occurred and the slope of the breakthrough curve was high.

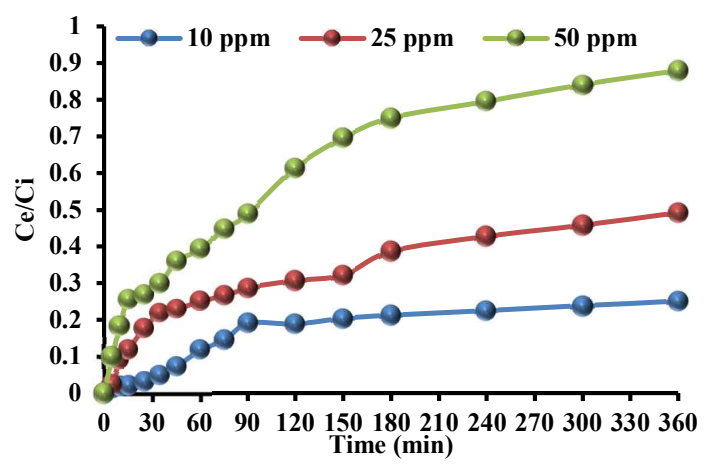

Figure 7: Effect of initial concentrations on the removal of $\mathrm{CR}$ at initial conditions $\mathrm{pH} 6,(\mathrm{Hs}=4 \mathrm{~cm}), 6 \mathrm{~L} / \mathrm{hr}$ and $250 \mathrm{cc} / \mathrm{min}$.

\section{a) Mass transfer}

Several authors proposed generalized correlation to predict the mass transfer coefficient $\left(\mathrm{K}_{\mathrm{L}}\right)$ in continuous systems. Fluidized bed reactor offers high available surface area, since there is no contact between particles, and contact of the entire surface with the wastewater. Segregation of the adsorbent particles occurs in fluidized bed adsorber, so that nearly its fully capacity can be realized with this form of operation. Liquid solid mass transfer coefficient is one of the most important parameters for the design, scale-up and performance characterization of columns[27]. The three-phase circulating fluidized bed can increase the heat and mass transfer coefficients at a higher range of superficial liquid velocity, and minimizing the dead zone in the reacting or contacting system by means of the circulating fluidization mode[15]. Various studies have been done to determine the mass transfer in a bed and many correlations have been suggested to predict solid-liquid mass transfer coefficients for different systems, can use equation below to predicted of $\mathrm{K}_{\mathrm{L}}$ values[16].

$$
\begin{aligned}
& D_{m}=2.74 * 10^{-9}(M w t)^{-\frac{1}{3}} \\
& S h_{z}=2.27 S c^{0.33} R e_{z l}^{0.494} R e_{z g}^{0.178} G a^{-0.28} \\
& K_{l}=\frac{S h_{z} \cdot D_{m}}{d_{p}}
\end{aligned}
$$

When the liquid flow rate increased from 6 to $18 \mathrm{~L} / \mathrm{hr}, \mathrm{K}_{\mathrm{L}}$ values were increased from 3.63E-06 to 4.19E-06 for CR dye. The reason behind this action is that the change in flow rate will affect the film diffusion, but not the intraparticle diffusion. The higher the flow rate the smaller the film resistance to mass transfer and larger $\mathrm{K}_{\mathrm{L}}$ values were tabulated in Table 3.

Table 3: Mass transfer coefficient $K_{L}$ values of $C R$ at different operating conditions.

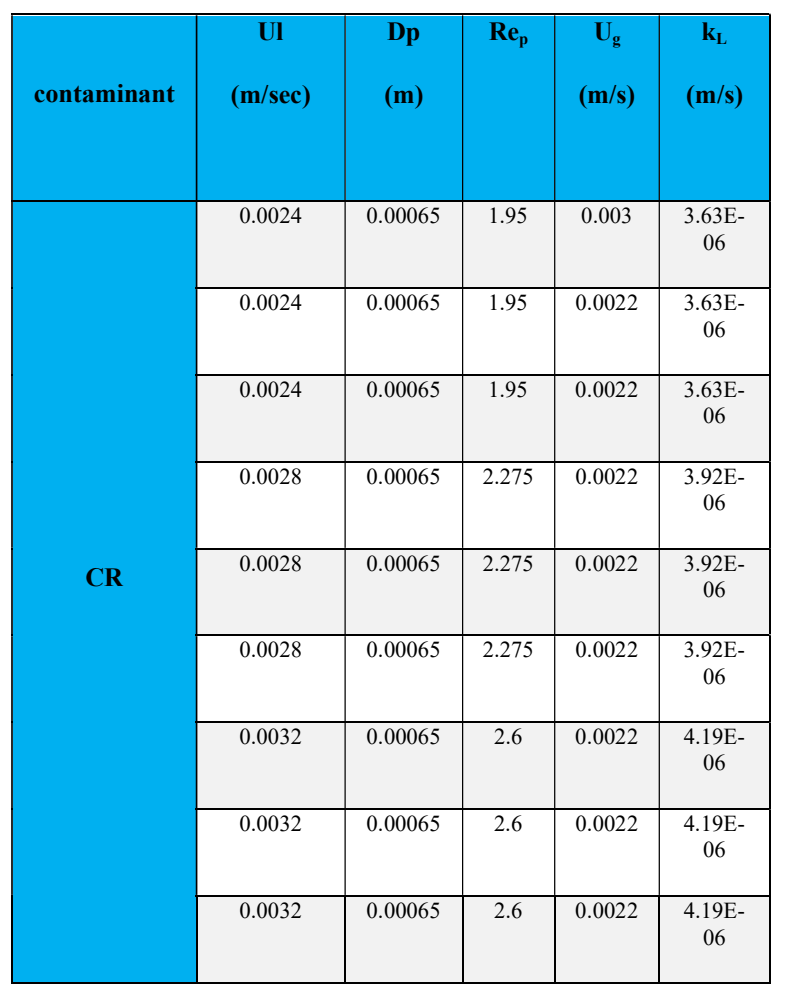




\section{5- Conclusions}

Eichhornia crassipes was found to be feasible media for use as a bed column for the removal of CR from contaminated water.A fluidized -bed column was used to investigate the sorption of $\mathrm{CR}$ studied and it was depended on feed flow rate, initial CR concentration and bed height of adsorbent. The minimum fluidization velocity of bed were found equal to $1.6,2,2.5 \mathrm{~mm} / \mathrm{s}$ respectively for bed height of $2,4,6 \mathrm{~cm}$ respectively. The variation of liquid superficial velocity from 0.0024 to $0.0032 \mathrm{~m} / \mathrm{s}$ resulted an obvious depletion in sorption removal efficiency. When the flow rate increases the breakthrough curves become steeper. The variation of bed height from 2 to $6 \mathrm{~cm}$ for CR resulted in an obvious increase in biosorption capacity. Increasing initial contaminant concentration cause an increase in biosorption capacity. The mass transfer coefficient "KL" increased with increasing the liquid flow rate.

\section{Nomenclature}

\begin{tabular}{|l|l|}
\hline Abbreviation & Description \\
\hline CR & Congo Red \\
\hline EC & Eichhornia crassipes \\
\hline dp & Particle diameter \\
\hline GLSFB & $\begin{array}{l}\text { Gas-Liquis-Solid } \\
\text { Fluidized Bed }\end{array}$ \\
\hline Hs & Bed height \\
\hline Pd & Pressure drop \\
\hline PIS & Pistachio shell \\
\hline$D_{m}$ & Diffusivity coefficient \\
\hline$S h_{z}$ & $\begin{array}{l}\text { Modified Sherwood } \\
\text { number, } K_{\mathrm{L}} \cdot \mathrm{y}_{\mathrm{Z}} / \mathrm{D}_{\mathrm{m}}\end{array}$ \\
\hline $\mathrm{R} \mathrm{e}_{\mathrm{g}}$ & $\begin{array}{l}\text { Modified Reynolds } \\
\text { number for gas, } \mathrm{Ug} \rho_{\mathrm{g}} / \mathrm{a} \\
\mu_{\mathrm{g}}\end{array}$ \\
\hline $\mathrm{TEC}$ & Tetracyclin \\
\hline $\mathrm{Ug}$ & Gas velocity \\
\hline $\mathrm{UL}$ & Liquid velocity \\
\hline $\mathrm{Ulmf}$ & $\begin{array}{l}\text { Minimum fluidization } \\
\text { velocity }\end{array}$ \\
\hline $\mathrm{U}_{\mathrm{i}}$ & $\begin{array}{l}\text { The settling velocity of a } \\
\text { particle }\end{array}$ \\
\hline$\varepsilon$ & Bed voidage \\
\hline$V_{b}$ & $\begin{array}{l}\text { volume of wastewater } \\
\text { solution }\end{array}$ \\
\hline$V_{p}$ & Volume of particle \\
\hline$V_{\varepsilon}$ & Void volume \\
\hline$m_{p}$ & Mass of particles \\
\hline$\rho_{\mathrm{p}}$ & Real density of particles \\
\hline $\mathrm{H}$ & Bed height \\
\hline & \\
\hline &
\end{tabular}

\section{References}

[1] A. H. Faisal and L. A. Naji, "Simulation of Ammonia Nitrogen Removal from Simulated Wastewater by Sorption onto Waste Foundry
Sand Using Artificial Neural Network," Assoc. Arab Univ. J. Eng. Sci., vol. 26, no. 1, pp. 2834, Mar. 2019.

[2] A. Mohammed, "Biosorption of Lead, Copper , and Nickel onto Tea Waste: Equilibrium, and Kinetic Studies". Association of Arab Universities Journal of Engineering Sciences. no. 3, 2017.

[3] A. Mohammed, F. I. Abed, and F. I. Abed, "REMOVAL OF COPPER ION FROM WASTEWATER BY FLOTATION,”. Journal of Engineering. vol. 17, no. 6, 2011.

[4] A. Mohammed, T. J. Al-musawi, S. L. Kareem, M. Zarrabi, and A. M. Al-ma, "Simultaneous adsorption of tetracycline , amoxicillin , and ciprofloxacin by pistachio shell powder coated with zinc oxide nanoparticles," Arab. J. Chem., vol. 13, no. 3, pp. 4629-4643, 2020.

[5] A. Mohammed. "Biosorption of $\mathrm{Pb}$ ( II ) from aqueous solution by spent black tea leaves and separation by flotation separation by flotation,". Desalination and Water Treatment. vol. 3994, Pages 2028-2039, 2015.

[6] A. Najim, "Biosorption of Nickel Ions and Methylene Blue Dye from Simulated Wastewater by Three Phase Circulated Fluidized Bed Using Mixed Algae," M.S.C., Thesis, University of Baghdad, College of engineering, 2018.

[7] A. Najim, and A. A. Mohammed. " Biosorption of Methylene Blue from Aqueous Solution Using Mixed Algae". Iraqi Journal of Chemical and Petroleum Engineering Vol.19 No.4 , 1 11, 2018.

[8] D. Berihun."Removal of Chromium from Industrial Wastewater by Adsorption Using Coffee Husk". Journal of Material Sciences and Engineering. vol. 6, no. 2, pp. 6-11, 2017.

[9] F. Bin Abdurrahman, M. Akter, and M. Z. Abedin, "Dyes Removal From Textile Wastewater Using Orange Peels,". INTERNATIONAL JOURNAL OF SCIENTIFIC \& TECHNOLOGY RESEARCH. vol. 2, no. 9, 2013.

[10]F. H. Kamar, A. A. Mohammed, A. A. H. Faisal, A. C. Nechifor, and G. Nechifor, "Biosorption of Lead , Copper and Cadmium Ions from Industrial Wastewater Using Fluidized Bed of Dry Cabbage Leaves," REV.CHIM.(Bucharest), 67No. $6,2016$.

[11] G. L. Dotto and L. A. A. Pinto, “Adsorption of food dyes onto chitosan: Optimization process and kinetic,". Carbohydrate Polymers. vol. 84, no. 1, pp. 231-238, 2011.

[12] G. Naja and B. Volesky, "Behavior of the Mass Transfer Zone in a Biosorption Column,". 
Environ. Sci. Technol. vol. 40, no. 12, pp. 39964003, 2006.

[13]H. D. Bouras, A. R. Yeddou, N. Bouras, D. Hellel, M. D.Holtz, N. Sabaou, A. Chergui, and B. Nadjemia. "Biosorption of Congo red dye by Aspergillus carbonarius M333 and Penicillium glabrum Pg1: Kinetics, equilibrium and thermodynamic studies," Journal of the Taiwan Institute of Chemical Engineers. vol. 80, pp. 915-923, 2017.

[14]H. N. Abdulkareem and A. I. Alwared, "IMMOBILIZATION DRIED MIX OF ALGAE FOR COPPER REMOVAL Biosorbents," vol. 10.

[15]H. T. Shatub, S. N. Saleh, and A. A. Mohammed, "Measuring Particle Velocity Distribution in Circulating Fluidized Bed,". International Journal of Science and Research. vol. 6, no. 1, pp. 834-838, 2017.

[16] J. Abdi, M. Vossoughi, N. M. Mahmoodi, and I. Alemzadeh, "Synthesis of metal-organic framework hybrid nanocomposites based on GO and CNT with high adsorption capacity for dye removal," Chemical Engineering Journal Volume. vol. 326, pp. 1145-1158, 2017.

[17] J. H. Al-Baidhani and S. T. Al-Salihy, "Removal of heavy metals from aqueous solution by using low cost rice husk in batch and continuous fluidized experiments," International Journal of Chemical Engineering and Applications. vol. 7, no. 1, p. 6, 2016.

[18] J. Vidal, C. Espinoza, N. Contreras, and R. Salazar, "Elimination of industrial textile dye by electrocoagulation using iron electrodes,". Journal of the Chilean Chemical Society. vol. 2, pp. 2-7, 2017.

[19] L. A. Naji, S. H. Jassam, M. J. Yaseen, A. A. H. Faisal, and N. Al-Ansari, "Modification of Langmuir model for simulating initial $\mathrm{pH}$ and temperature effects on sorption process," Separation Science and Technology. pp. 1-8, Aug. 2019.

[20] M. A. Al-ghouti, J. Li, Y. Salamh, N. Al-laqtah, G. Walker, and M. N. M. Ahmad, "Adsorption mechanisms of removing heavy metals and dyes from aqueous solution using date pits solid adsorbent,". Journal of Hazardous Materials. vol. 176, pp. 510-520, 2010.

[21] M. Alshammari., M. F. Al Juboury, L. A. Naji, A. A. Faisal, H. Zhu, N. Al-Ansari , and M. Naushad. "Synthesis of a Novel Composite Sorbent Coated with Siderite Nanoparticles and its Application for Remediation of Water Contaminated with Congo Red Dye". International Journal of Environmental Research. 14, pages177-191. 2020.
[22] Mittal, J. Mittal, A. Malviya, and V. K. Gupta, "Adsorptive removal of hazardous anionic dye 'Congo red' from wastewater using waste materials and recovery by desorption,”. Journal of Colloid and Interface Science. vol. 340, no. 1, pp. 16-26, 2009.

[23] Mudhoo, A. Bhatnagar, M. Rantalankila, V. Srivastava, and M. Sillanpää, "Endosulfan removal through bioremediation, photocatalytic degradation , adsorption and membrane separation processes: A review," . Chemical Engineering Journal. vol. 360, no. December 2018, pp. 912-928, 2019.

[24] M. E. Soltan, and M. N. Rashed, "Laboratory study on the survival of water hyacinth under several conditions of heavy metal concentrations,". Advances in Environmental Research. vol. 7, pp. 321-334, 2003.

[25] M. Z. B. Mukhlish, M. S. I. Mazumder, K. Ferdous, D. M. R. Prasad, and Z. Hassan, "Uptake of Indosol Dark-blue GL dye from aqueous solution by water hyacinth roots powder: adsorption and desorption study," . International Journal of Environmental Science and Technology. pp. 1027-1034, 2014.

[26] P. Gharbani, S. M. Tabatabaii, and A. Mehrizad, "Removal of Congo red from textile wastewater by ozonation,". International Journal of Environmental Science \& Technology. vol. 5, no. 4, pp. 495-500, 2008.

[27] P. Taylor, S. Devi, A. Murugappan, and R. R. Kannan, "Sorption of Reactive blue 19 onto freshwater algae and seaweed,". Desalination and Water Treatment. pp. 37-41, 2014.

[28] Q. Li., Y. Li, X. Ma, Q. Du, K. Sui, D. Wang, C. Wang, H. 1. Li, and Y. Xia. "Filtration and adsorption properties of porous calcium alginate membrane for methylene blue removal from water,". Chemical Engineering Journal. vol. 316, pp. 623-630, 2017.

[29] R. Ahmad, "Studies on adsorption of crystal violet dye from aqueous solution onto coniferous pinus bark powder ( CPBP ),". Journal of Hazardous Materials vol. 171, pp. 767-773, 2009.

[30] R. K. Mahajan and V. K. Gupta, "Modification of surface behaviour of Eichhornia crassipes using surface active agent: an adsorption study". Journal of Industrial and Engineering Chemistry. vol. 21, pp. 189-197, 2015.

[31]R. Rehman1, I. Manzoor, and L. Mitu. "Isothermal study of Congo Red dye biosorptive removal from water by Solanum tuberosum and Pisum sativum peels in economical way". Chemical Society of Ethiopia and The Authors vol. 32, no. 2, pp. 213-223, 2018.

[32] Sabah, and A. I. Alwared. " Adsorption of Congo red Dye from Aqueous Solution onto Wheat Husk 
in a Fluidized Bed Reactor". Iraqi Journal of Chemical and Petroleum Engineering. Vol.20 No.4 (December 2019) $55-60$.

[33] S. L. Kareem. A. A. Mohammed, "Adsorption of tetracycline fom wastewater by using Pistachio shell coated with $\mathrm{ZnO}$ nanoparticles : Equilibrium , kinetic and isotherm studies," Alexandria Engineering Journal. vol. 58, no. 3, pp. 917-928, 2019.

[34] T. J. Al-Musawi." Multicomponent biosorption of heavy metals using fluidized algal biomass bed." ph. D., Thesis, University of Baghdad, College of engineering, 2012.

[35] T. K. Roy and N. K. Mondal, "Biosorption of Congo Red from aqueous solution onto burned root of Eichhornia crassipes biomass," Applied Water Science., vol. 7, no. 4, pp. 1841-1854, 2017.

[36] V. K. Garg, R. Gupta, A. B. Yadav, and R. Kumar, "Dye removal from aqueous solution by adsorption on treated sawdust,".
Bioresource Technology. vol. 89, no, pp. 121124, 2003.

[37] W. C. Wanyonyi, J. M. Onyari, and P. M. Shiundu, "Adsorption of Congo red dye from aqueous solutions using roots of Eichhornia crassipes: kinetic and equilibrium studies," Energy Procedia, vol. 50, pp. 862-869, 2014.

[38] Y. Ho, T. Chiang, and Y. Hsueh, "Removal of basic dye from aqueous solution using tree fern as a biosorbent". Process Biochemistry. vol. 40, pp. 119-124, 2005.

[39] Z. Hu, H. Chen, F. Ji, and S. Yuan, "Removal of Congo Red from aqueous solution by cattail root," Journal of Hazardous Materials., vol. 173, no. 1-3, pp. 292-297, 2010.

[40] Z. R. Komy, W. H. Abdelraheem, and N. M. Ismail, "Biosorption of $\mathrm{Cu} 2+$ by Eichhornia crassipes: Physicochemical characterization, biosorption modeling and mechanism," Journal of King Saud University - Science., vol. 25, no. $1, \quad$ pp. 47-56, 2013.

\title{
إزالة الكونغو الأحمر (CR) من محلول مائي عن طريق تعميم السرير الميعة (CFB)
}

\author{
حمزة قاسم عليم، أحمد عبد محمد2 \\ hamzaashter@gmail.com قسم الهندسة البيئية ،كلية الهندسة ، جامعة بغداد، بغداد، العراق، \\ ahmed.abedm@yahoo.com قسم الهندسة البيئية، كلية الهندسة ، جامعة بغداد، بغداد، العراق، \\ "الباحث المثثل: حمة قاسم علي ، البريـ الالكتروني: " hamzaashter@yahoo.com \\ شر في: 30 حزيران 2021
}

الخلاصة ـ في هذه الدراسة ، تم تبني طبقة مميعة متداولة لإزالة الكونغو الأحمر من مياه الصرف الصحي باستخدام

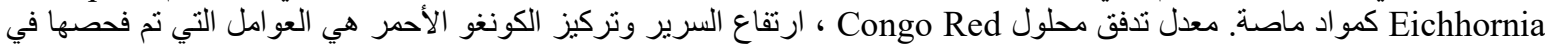

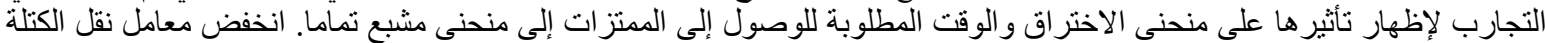

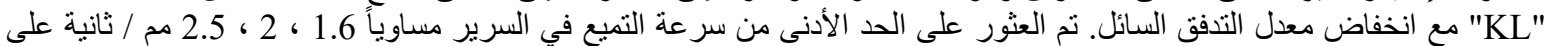

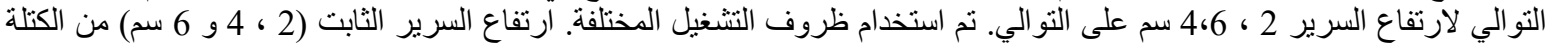

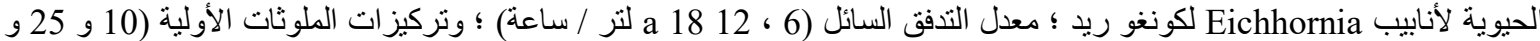

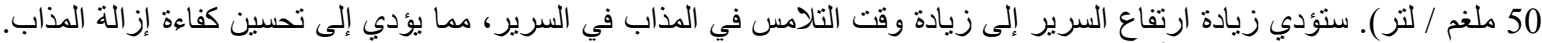
زيادة معدل التدفق والتركيز الأولي يزيد منئ من معدل نقل الكتلة. الكلمات الرئيسية - تكتب 3-5 كلمات رئيسية وتكون منفصلة

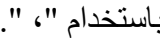

$$
\text { الكلمات الرئيسية ـ الكونغو الأحمر ، السرير المميع الدائري ، الحد الأدنى لسرعة التميع ، ارتفاع السرير ، زهرة النيل. }
$$

